\title{
Tumor-associated macrophages in solid tumor: friend or foe
}

I am delighted to be the editor for a focused series "Tumor Associated Macrophages in Solid Tumor: Friend or Foe". Tumor-associated macrophages (TAMs) are the heterogeneous and plastic, innate immune cells population of the tumor microenvironment (TME) and their functions are mostly depending upon local microenvironment. In various solid tumors, they are the major constituent of the TME and associated with tumor initiation, progression, angiogenesis, metastasis, and resistance to therapy. Besides, several studies have also been highlighted that TAMs can also have an anti-tumor effect if properly activated. Although it is necessary to understand the nature of TAMs for the effective therapeutic approach in solid tumors.

The focused series aims to highlight the current status of TAMs research in context to solid tumors in a preclinical and clinical setting. We have invited distinguished scientists from the different onco-immunology field for this focused series. I hope, the reviews will help the reader to understand in detail macrophages topographical and temporal heterogeneity and functional diversity in different tumor types.

\section{Acknowledgments}

Funding: None.

\section{Footnote}

Provenance and Peer Review: This article was commissioned by the editorial office, Annals of Translational Medicine for the series "Tumor Associated Macrophages in Solid Tumor: Friend or Foe". The article did not undergo external peer review.

Conflicts of Interest: The author has completed the ICMJE uniform disclosure form (available at http://dx.doi.org/10.21037/ atm-2020-tam-05). The series "Tumor Associated Macrophages in Solid Tumor: Friend or Foe" was commissioned by the editorial office without any funding or sponsorship. GP served as the unpaid Guest Editor of the series and serves as an unpaid editorial board member of Annals of Translational Medicine from Sep 2019 to Aug 2021. The author has no other conflicts of interest to declare.

Ethical Statement: The author is accountable for all aspects of the work in ensuring that questions related to the accuracy or integrity of any part of the work are appropriately investigated and resolved.

Open Access Statement: This is an Open Access article distributed in accordance with the Creative Commons AttributionNonCommercial-NoDerivs 4.0 International License (CC BY-NC-ND 4.0), which permits the non-commercial replication and distribution of the article with the strict proviso that no changes or edits are made and the original work is properly cited (including links to both the formal publication through the relevant DOI and the license). See: https://creativecommons.org/licenses/by-nc$\mathrm{nd} / 4.0 /$. 


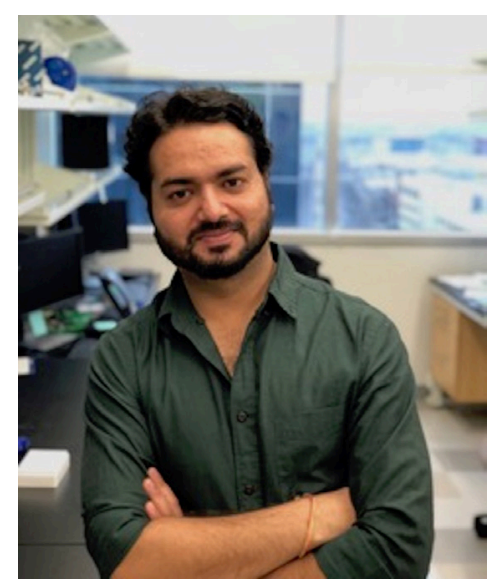

Gaurav Pandey

Gaurav Pandey, PhD

Department of Radiation Oncology, Centre for Human Immunology and Immunotherapy Programs, Washington University School of Medicine, St. Louis, MO, USA. (Email: gpandey@wustl.edu) Submitted Jul 11, 2020. Accepted for publication Jul 22, 2020. doi: $10.21037 /$ atm-2020-tam-05

View this article at: http://dx.doi.org/10.21037/atm-2020-tam-05

Cite this article as: Pandey G. Tumor-associated macrophages in solid tumor: friend or foe. Ann Transl Med 2020;8(16):1027. doi: 10.21037/atm-2020-tam-05 